\title{
Preliminary Biological Activity Screening of Plectranthus spp. Extracts for the Search of Anticancer Lead Molecules
}

\author{
Epole Ntungwe ${ }^{1,2} \mathbb{D}$, Eva María Domínguez-Martín ${ }^{1,2} \mathbb{D}$, Catarina Teodósio ${ }^{1}$, Silvia Teixidó-Trujillo ${ }^{3}$, \\ Natalia Armas Capote ${ }^{3}$, Lucilia Saraiva ${ }^{4}\left(\mathbb{D}\right.$, Ana María Díaz-Lanza ${ }^{(\mathbb{D}}$, Noélia Duarte ${ }^{5}$ and Patrícia Rijo ${ }^{1,5}, *(\mathbb{D}$
}

Citation: Ntungwe, E.;

Domínguez-Martín, E.M.; Teodósio,

C.; Teixidó-Trujillo, S.; Armas Capote,

N.; Saraiva, L.; Díaz-Lanza, A.M.;

Duarte, N.; Rijo, P. Preliminary

Biological Activity Screening of

Plectranthus spp. Extracts for the Search of Anticancer Lead Molecules.

Pharmaceuticals 2021, 14, 402. https://

doi.org/10.3390/ph14050402

Academic Editor: Maria Matilde

Soares Duarte Marques

Received: 6 April 2021

Accepted: 20 April 2021

Published: 23 April 2021

Publisher's Note: MDPI stays neutral with regard to jurisdictional claims in published maps and institutional affiliations.

Copyright: (c) 2021 by the authors. Licensee MDPI, Basel, Switzerland. This article is an open access article distributed under the terms and conditions of the Creative Commons Attribution (CC BY) license (https:// creativecommons.org/licenses/by/ $4.0 /)$.
1 CBIOS-Universidade Lusófona Research Center for Biosciences \& Health Technologies, Universidade Lusófona de Humanidades e Tecnologias, Campo Grande 376, 1749-024 Lisboa, Portugal; ntungweepolengolle@yahoo.com (E.N.); evam.dominguez@uah.es (E.M.D.-M.); catarina.teodosio@gmail.com (C.T.)

2 Department of Biomedical Sciences, Faculty of Pharmacy, University of Alcalá de Henares, Ctra. A2, Km 33.100_Campus Universitario, 28805 Alcalá de Henares, Spain; ana.diaz@uah.es

3 Centro Atlántico del Medicamento S.A., Avenida Trinidad 61, $7^{\mathrm{a}}$ Planta, Torre Agustín Arévalo, 38204 La Laguna, Tenerife, Spain; teixido.silvia@gmail.com (S.T.-T.); nataliaarmas@ceamedsa.com (N.A.C.)

4 LAQV/REQUIMTE, Laboratório de Microbiologia, Departamento de Ciências Biológicas, Faculdade de Farmácia, Universidade do Porto, Rua de Jorge Viterbo Ferreira n. ${ }^{\circ}$ 228, 4050-313 Porto, Portugal; lucilia.saraiva@ff.up.pt

5 Instituto de Investigação do Medicamento (iMed.ULisboa), Faculdade de Farmácia, Universidade de Lisboa, 1649-003 Lisboa, Portugal; mduarte@ff.ulisboa.pt

* Correspondence: patricia.rijo@ulusofona.pt

Abstract: Plectranthus species (Lamiaceae) have been employed in traditional medicine and this is now validated by the presence of bioactive abietane-type diterpenoids. Herein, sixteen Plectranthus acetonic extracts were prepared by ultrasound-assisted extraction and their biological activity was screened. The antimicrobial activity of each extract was screened against yeasts, and Gram-positive and Gram-negative bacteria. The P. hadiensis and P. mutabilis extracts possessed significant activity against Staphylococcus aureus and Candida albicans (microdilution method). Moreover, all extracts showed antioxidant activity using the DPPH method, with $P$. hadiensis and P. mutabilis extracts having the highest scavenging activities. Selected by the Artemia salina model, P. hadiensis and P.ciliatus possessed low micromolar anti-proliferative activities in human colon, breast, and lung cancer cell lines. Furthermore, the most bioactive extract of $P$. hadiensis leaves and the known abietane diterpene, $7 \alpha$-acetoxy-6 $\beta$-hydroxyroyleanone isolated from this plant, were tested against the aggressive type triple negative breast cancer (MDA-MB-231S). P. hadiensis extract reduced the viability of MDA-MB-231S cancer cell line cells, showing an $\mathrm{IC}_{50}$ value of $25.6 \mu \mathrm{g} / \mathrm{mL}$. The $\mathrm{IC}_{50}$ value

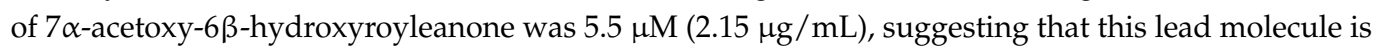
a potential starting tool for the development of anti-cancer drugs.

Keywords: Plectranthus; royleanone; $7 \alpha$-acetoxy-6 $\beta$-hydroxyroyleanone; ent-abietane; antitumoral activity; antimicrobial activity; antioxidant

\section{Introduction}

Over the centuries, plants and natural products derived from plants have been the basis of traditional medicine. Nowadays, plant-based medicines have been playing an important role in drug discovery and development. They are also widely employed in various public health practices as they are safe, cost-effective, and possess unique chemical diversity $[1,2]$. Cancer remains one of the leading causes of death globally, with approximately 18.1 million new cases and 9.6 million cancer-related deaths in 2018, according to the World Health Organization [3]. Furthermore, several types of chemotherapies used are ineffective and generate unwanted adverse side effects [4,5]. Similarly, there is an increasing number of cases of bacterial infections that are resistant to current antibiotics and are 
difficult or impossible to treat [6]. Currently, there is an emerging interest in developing drugs that overcome the problems stated above by using natural compounds.

Plectranthus L' Herit. is a major genus of the Lamiaceae family comprising about 300 species mainly distributed in the summer-rainfall savannahs and forested regions of tropical Africa, Asia, and Australia $[7,8]$. Most of the Plectranthus species are soft trailing semi-succulent to succulent herbs or shrubs and their stems, leaves, roots, and tubers are frequently used as traditional medicines for the treatment of various illnesses, including respiratory, digestive, and liver ailments [9]. Phytochemical studies on some species of Plectranthus revealed the presence of a large number of diterpenes and triterpenes [10,11]. Isolated terpenes from Plectranthus species are reported to possess antibacterial [12-14], antitumoral [15-18], antifungal [12,19], insecticidal [20], and antiplasmodial [20] activities. Moreover, our group has been focused on the phytochemical study of Plectranthus species and we have reported abietane diterpenoids with diverse bioactivity $[16,17,21-25]$. Therefore, the screening of other Plectranthus spp. extracts aiming at finding new sources of biologically active natural products is warranted.

Herein, sixteen Plectranthus species were screened for their bioactivity (antioxidant, antimicrobial activities, and general toxicity) and the main compound of the most bioactive extract was identified. To the best of our knowledge, the scientific literature concerning these species is scarce or even non-existent. P. hadiensis was earlier reported to have ethnopharmacological activity and to be a rich source of ent-abietane diterpenes [11]. This work aims to screen the antimicrobial, antioxidant, and cytotoxic properties of several Plectranthus spp. extracts and identifying the component in the most bioactive extract that may be responsible for its bioactivity.

\section{Results and Discussion}

All sixteen Plectranthus spp. extracts were prepared using ultrasound-assisted extraction in acetone. Previous studies of Plectranthus species showed that acetonic extracts are rich in diterpenoids, and high extraction yields are obtained when the ultrasound extraction method is carried out [21]. Therefore, using this extraction method, sixteen acetonic extracts of Plectranthus spp. were prepared. The extraction of all extracts was done in triplicate under the same conditions. All extracts were solubilized in DMSO $(10 \mathrm{mg} / \mathrm{mL})$ and stored at $-20^{\circ} \mathrm{C}$ until further analysis for their biological assays. P. mutabilis had the highest extraction yield $(30.00 \% w / w)$ (Table 1$)$.

The antioxidant activity of the extracts was quantitatively determined using the DPPH (2,2-diphenyl-1-picrylhydrazyl) scavenging radical assay. The antioxidant activity of the extracts was compared with quercetin, a well-known pure compound used as a positive control to understand the potential antioxidant activity of the extracts screen. The antioxidant activity indicates the capacity to quench reactive oxygen species (ROS), leading to decreased oxidative stress [26]. The results of the free radical scavenging capacity of extracts at a concentration of $10 \mu \mathrm{g} / \mathrm{mL}$ are shown in Table 1. P. mutabilis and P. hadiensis had the highest scavenging activity of $46.14 \%$ and $36.24 \%$, respectively. These results are also in agreement with other studies with Plectranthus extracts, in which P. madagascarensis $P$. neochilus, $P$. barbatus and $P$. verticillatus extracts showed free radical scavenging abilities [27]. This could be due to the presence of abietane diterpenes known for their antioxidant activity. Recently, findings concerning the antioxidant activity of abietane diterpenes isolated from Plectranthus spp. suggest that the quinone moiety present in these compounds is probably responsible for their biological activity [28]. The presence of the 12-OH group and the carbonyl group at position C-7 ( $p$-position) could serve as hydrogen- and/or electron-donating moieties, resulting in the formation of stable quinone derivatives [29].

To evaluate the antimicrobial activity, the extracts were screened against Gram-positive (Staphylococcus aureus, Enterococcus faecalis) and Gram-negative (Pseudomonas aeruginosa and Escherichia coli) bacteria and yeasts (Candida albicans and Saccharomyces cerevisiae) using the well diffusion assay. The antimicrobial activity of each acetonic extract was first screened by 
the well diffusion method at a concentration of $1 \mathrm{mg} / \mathrm{mL}$. Only P. hadiensis and P. mutabilis extracts showed antimicrobial activity against $S$. aureus with inhibition zones of $16 \mathrm{~mm}$ and $15 \mathrm{~mm}$, respectively. None of the extracts showed significant antibacterial activity against $E$. faecalis and Gram-negative bacteria. These results are in agreement with previous works on Plectranthus spp. $[17,30]$ showing that only Gram-positive bacteria are sensitive to Plectranthus acetonic extracts $[27,31]$. When the zone of inhibition of the extracts was compared with the negative control, it was found that nine extracts (P. ciliatus, P. welshii, P. mzumbulensis, P. inflexus, P. lucidus, P. xerophylus, P. lippio, P. hadiensis, and P. mutabilis.) exhibited antimicrobial activity against $C$. albicans $(10-11 \mathrm{~mm})$. The remaining did not display any antimicrobial effects, showing inhibition zones similar to the negative control (data not shown).

Table 1. Extraction yields (dry weight $\% w / w$ ), antioxidant activity, and general toxicity of sixteen Plectranthus spp. acetonic extracts.

\begin{tabular}{|c|c|c|c|c|}
\hline \multirow{2}{*}{ Scientific Name } & \multirow{2}{*}{$\begin{array}{c}\text { Yield } \\
(\% w / w)^{a}\end{array}$} & \multirow{2}{*}{ Antioxidant Activity ${ }^{b}(\%)$} & \multicolumn{2}{|c|}{ General Toxicity } \\
\hline & & & ${ }^{*}$ Mortality (\%) & $\mathrm{LC}_{50}(\mu \mathrm{g} / \mathrm{mL}) * *$ \\
\hline P. swynnertonii S. Moore † & 3.89 & $20.24 \pm 0.01$ & $65.88 \pm 5$ & $0.036 \pm 1.69$ \\
\hline P. ciliatus E. Mey + & 11.86 & $13.21 \pm 0.01$ & $60.14 \pm 0.44$ & $0.504 \pm 1.13$ \\
\hline P. mutabilis Codd. + & 30.03 & $46.14 \pm 0.02$ & $51.50 \pm 0.07$ & $0.984 \pm 2.92$ \\
\hline $\begin{array}{l}\text { P. hadiensis (Forssk.) Schweinf. } \\
\text { Ex Sprenger }+\end{array}$ & 13.49 & $36.24 \pm 0.04$ & $43.65 \pm 3.04$ & $0.88 \pm 4.87$ \\
\hline P. cylindraceus Hochst, ex Benth † & 9.68 & $19.19 \pm 0.07$ & $43.50 \pm 5.66$ & $0.55 \pm 1.96$ \\
\hline $\begin{array}{c}\text { P. lucidus (Benth.) Van Jaarsv. } \\
\text { and T.J. Edwards † }\end{array}$ & 6.29 & $23.96 \pm 0.09$ & $38.81 \pm 3.75$ & $1.053 \pm 4.61$ \\
\hline P. inflexus (Thunb.) Vahl ex Benth $\dagger$ & 10.97 & $0.16 \pm 0.05$ & $38.70 \pm 3.35$ & $0.986 \pm 2.87$ \\
\hline P. lippio. Druce & 2.09 & $30.5 \pm 0.14$ & $24.70 \pm 6.22$ & $\mathrm{~N} / \mathrm{A}$ \\
\hline P. crassus N.E.Br. $\dagger$ & 7.77 & $27.27 \pm 0.01$ & $31.16 \pm 1.29$ & $\mathrm{~N} / \mathrm{A}$ \\
\hline P. mzimvubuensis Van Jaarsv. $†$ & 7.79 & $22.47 \pm 0.05$ & $33.95 \pm 1.63$ & $\mathrm{~N} / \mathrm{A}$ \\
\hline P. xerophylus Codd & 10.16 & $20.15 \pm 0.02$ & $30.48 \pm 3.24$ & $\mathrm{~N} / \mathrm{A}$ \\
\hline P. welshii & 2.15 & $15.06 \pm 0.03$ & $23.71 \pm 0.60$ & $\mathrm{~N} / \mathrm{A}$ \\
\hline P. petiolaris E. Mey ex Benth. & 11.07 & $14.45 \pm 0.01$ & $23.42 \pm 4.15$ & $\mathrm{~N} / \mathrm{A}$ \\
\hline P. woodii Gürke & 8.51 & $13.04 \pm 0.01$ & $29.95 \pm 6.01$ & $\mathrm{~N} / \mathrm{A}$ \\
\hline P. welwitschii (Briq. Codd) & 3.59 & $12.63 \pm 0.03$ & $25.17 \pm 5.54$ & $\mathrm{~N} / \mathrm{A}$ \\
\hline P. spicatus E. Mey & 4.75 & $10.57 \pm 0.02$ & $27 \pm 0.28$ & $\mathrm{~N} / \mathrm{A}$ \\
\hline Positive control & $\mathrm{N} / \mathrm{A}$ & $99.47 \pm 0.10$ & $98.89 \pm 2.48$ & $\mathrm{~N} / \mathrm{A}$ \\
\hline DMSO & $\mathrm{N} / \mathrm{A}$ & $\mathrm{N} / \mathrm{A}$ & $21.87 \pm 0.44$ & $\mathrm{~N} / \mathrm{A}$ \\
\hline
\end{tabular}

${ }^{a}$ (mg of extracts/ g of the dried plant). ${ }^{\mathrm{b}}$ Antioxidant activity (\%): Quercetin a potent free radical scavenging capacity was used as a positive control. Data are mean \pm SD. * Screening of the Plectranthus spp. extracts for general toxicity at a concentration of $10 \mu \mathrm{g} / \mathrm{mL}$ using the Artemia salina test $(24 \mathrm{~h}) .{ }^{* *} \mathrm{LC}_{50}$ values $(\mu \mathrm{g} / \mathrm{mL})$ for the most active extracts. Positive control = Potassium dichromate $(10 \mu \mathrm{g} / \mathrm{mL})$. Data are mean $\pm \mathrm{SD}$ was calculated from three independent experiments and compared to DMSO $(\dagger p<0.001)$. Lethal concentration $(\%)=$ (Total A.salina - Alive A.salina)/(Total A.salina) $\times 100$ was used to calculate the lethal concentration of all extracts. N/A—not applicable.

As the initial screening using the well diffusion assay identified P. hadiensis and P. mutabilis extracts as possessing the most promising antimicrobial activities, further studies were carried out to evaluate the minimum inhibitory concentration (MIC) and minimum bactericidal concentration (MBC) or minimum fungicidal concentration (MFC) against the susceptible strains (Table 2). The MIC values ranged from $3.91 \mu \mathrm{g} / \mathrm{mL}$ to $125 \mu \mathrm{g} / \mathrm{mL}$. P. hadiensis was the most active extract, exhibiting a MIC value of $3.91 \mu \mathrm{g} / \mathrm{mL}$ against the methicillin-resistant $S$. aureus strain (MRSA), similar to that observed for the positive control $(1.95 \mu \mathrm{g} / \mathrm{mL})$. The MBC/MFC values ranged from 62.5 to $250 \mu \mathrm{g} / \mathrm{mL}$. It is possible to conclude that the extracts are mainly bacteriostatic rather than bactericidal [32].

To identify the most promising extracts with cytotoxic activity, the screening of general toxicity using the Artemia salina model was carried out. This assay was employed to screen the sixteen extracts because it is low-cost, rapid, convenient, and requires only a relatively small amount of sample $[31,33]$. All of the acetonic extracts were tested at $10 \mu \mathrm{g} / \mathrm{mL}$ with values ranging from 23.42 to $65.88 \%$ mortality (see Table 1 ). The most active extracts were further studied to obtain the $\mathrm{LC}_{50}$ values at concentrations of $0.1,0.5$, and $1 \mathrm{mg} / \mathrm{mL}$, 
after $24 \mathrm{~h}$ of exposure. The most toxic extracts (P. mutabilis, P. swynnertonii, P. hadiensis, $P$. ciliatus, and $P$. cylindraceus) with $\mathrm{LC}_{50} \leq 1 \mu \mathrm{g} / \mathrm{mL}$ (see Table 1 ) were then evaluated on human-derived cancer cell lines.

Table 2. MIC and MBC/MFC $(\mu \mathrm{g} / \mathrm{mL})$ values of the most active acetonic extracts.

\begin{tabular}{ccccccc}
\hline \multirow{2}{*}{ Extracts } & \multicolumn{3}{c}{ MIC $(\mu \mathrm{g} / \mathrm{mL})$} & \multicolumn{3}{c}{ MBC/MFC $(\mu \mathrm{g} / \mathrm{mL})$} \\
\cline { 2 - 7 } & S. aureus & MRSA & C. albicans & S. aureus & MRSA & C. albicans \\
\hline Positive Control & 3.91 & 1.95 & $<0.48$ & - & - & - \\
P. mutabilis & 31.25 & 31.25 & 125 & 250 & 250 & 125 \\
P. hadiensis & 15.62 & 3.91 & 62.5 & 250 & 250 & 62.5 \\
\hline
\end{tabular}

Positive controls (1 mg/mL): Gram-positive = vancomycin, Gram-negative = norfloxacin, yeast = nystatin, Negative control = DMSO, methicillin-resistant Staphylococcus aureus $=$ MRSA.

The cytotoxic activity was determined by the sulforhodamine B (SRB) assay in three different cancer cell lines: colon colorectal carcinoma (HCT116), human breast adenocarcinoma (MCF-7), and lung cancer carcinoma (NCI-H460). The $\mathrm{IC}_{50}$ values in all the cell lines tested ranged from $2.25 \mu \mathrm{g} / \mathrm{mL}$ to $36 \mu \mathrm{g} / \mathrm{mL}$ (Table 3). According to the National Cancer Institute (NCI), crude extracts that possess $\mathrm{IC}_{50} \leq 500 \mu \mathrm{g} / \mathrm{mL}$ are of potential interest for further studies [34] and a possible candidate for further development of cancer therapeutic agents. Thus, most of the selected extracts showed potential values, and $P$. hadiensis and $P$. ciliatus seem to be potential sources of lead anticancer molecules. P. ciliatus extract was most active against the colon cell line (HCT116), whereas the P. hadiensis extract was the most active against the breast (MCF-7) and lung (NCI-H460) cell lines with the lowest $\mathrm{IC}_{50}$ value in the MCF-7 cell lines. For this reason, this extract was further tested against the aggressive type triple-negative breast cancer (MDA-MB-231S). MCF-7 hormone receptors expressing breast cancers have a more favorable prognosis as opposed to triple-negative breast cancer (TNBC), which is characterized by a poor treatment outcome [35]. This cell line is a highly metastatic triple-negative breast cancer cell line that does not display estrogenic receptors (ER), progesterone receptors (PR), or human epidermal growth factor receptor 2 (HER2), and is thus difficult to treat [21]. P. hadiensis acetonic extract had a growth inhibition effect on MDA-MB-231 cancer cells ( $\mathrm{IC}_{50}$ value of $25.6 \mu \mathrm{g} / \mathrm{mL}$, Table 3). Many studies have attributed the cytotoxicity of Plectranthus extracts to the presence of royleanone-type abietane diterpenoids with known anticancer activities [18,36]. The abietane-type diterpenoid royleanones are a highly bioactive group of lead molecules, important for the development of new anticancer drugs [22] Given the good levels of bioactivity of $P$. hadiensis extract in all the cell lines tested, it was selected to identify its main bioactive component.

Table 3. $\mathrm{IC}_{50}(\mu \mathrm{g} / \mathrm{mL})$ values for five selected acetonic extracts in HCT116, MCF-7, H460 and MDA-MB231S cell lines.

\begin{tabular}{ccccc}
\hline & HCT116 & H460 & MCF-7 & MDA-MB231S ** \\
\hline P. hadiensis & $3.45 \pm 0.35$ & $3.00 \pm 0.10$ & $2.90 \pm 0.10$ & 25.6 \\
P. ciliatus & $2.25 \pm 0.75$ & $6.45 \pm 0.05$ & $6.70 \pm 0.30$ & N/A \\
P. swynnertonii & $7.95 \pm 0.35$ & $13.50 \pm 0.50$ & $15.05 \pm 0.02$ & N/A \\
P. cylindraceus & $10.25 \pm 0.75$ & $12.50 \pm 0.50$ & $12.00 \pm 1.00$ & N/A \\
P. mutabilis & $28.00 \pm 2.00$ & $36.00 \pm 2.00$ & $35.00 \pm 1.00$ & N/A \\
Doxorubicin & $0.05 \pm 3.24$ & $0.29 \pm 2.32$ & $0.08 \pm 4.10$ & $0.07 \pm 0.01$ \\
\hline
\end{tabular}

* The concentration that reduces growth by $50 \%\left(\mathrm{IC}_{50}\right)$ was determined by sulforhodamine $\mathrm{B}$ assay after $48 \mathrm{~h}$ treatment. Data are mean \pm SEM of $4-5$ independent experiments. ${ }^{* *} \mathrm{IC}_{50}(\mu \mathrm{g} / \mathrm{mL})$ of the most bioactive P. hadiensis acetonic extract in MDA-MB231S cancer cell lines. DMSO was used as the negative control. N/A—not applicable.

To unveil the chemical profile of the most bioactive $P$. hadiensis acetonic extract, and to identify the main compound responsible for the tested bioactivity, an HPLC-DAD study was carried out. The chromatogram revealed that the known ent-abietane diterpene, 
$7 \alpha$-acetoxy-6 $\beta$-hydroxyroyleanone, Roy (Figure 1) was the major compound in the extract (Supplementary Material). To isolate this diterpene, a bio-guided column and the preparative chromatographic procedure were carried out. Its structure was confirmed through comparison of its spectroscopic data (Supplementary Material) to those described in the literature $[12,29,37]$.<smiles>CC(I)C1=C(O)C(=O)C2=C(C1=O)[C@H](O)[C@H](O)[C@]1(C)C(C)(C)CCC[C@]21C</smiles>

Figure 1. Chemical structure of $7 \alpha$-acetoxy-6 $\beta$-hydroxyroyleanone.

In previous studies, $7 \alpha$-acetoxy- $6 \beta$-hydroxyroyleanone showed cytotoxic activity against three human cell lines, namely, sensitive non-small cell lung carcinoma, NCI-H460 cell line ( $\left.\mathrm{IC}_{50} 2.7 \pm 0.4\right)$, multidrug-resistant non-small cell lung carcinoma cell line with P-glycoprotein overexpression. NCI-H460/R ( IC $\left._{50} 3.1 \pm 0.4\right)$, and human embryonal bronchial epithelial (MCR-5) cells ( $\left.\mathrm{IC}_{50} 8.6 \pm 0.4\right)$ [21,38]. Given its cytotoxic properties, the presence of this compound in P. hadiensis acetonic extract may partially explain, the foreseen properties of the extract. To further explore its cytotoxicity, additional studies were performed.

The preliminary toxicity of the isolated $7 \alpha$-acetoxy- $6 \beta$-hydroxyroyleanone (Roy) was evaluated using the Brine shrimp lethality bioassay, which gave a percentage mortality of $30.95 \%$. The cytotoxicity of $7 \alpha$-acetoxy-6 $\beta$-hydroxyroyleanone was further tested in the TNBC, MDA-MB231S cell line using the MTT assay. It had an $\mathrm{IC}_{50}$ value of $5.5 \mu \mathrm{M}=$ $2.15 \mu \mathrm{g} / \mathrm{mL}$ (Supplementary Information Figure S4), being approximately 12-fold more active than the corresponding extract (MDA-MB231S $\mathrm{IC}_{50}$ value $=25.6 \mu \mathrm{g} / \mathrm{mL}$ ). This diterpene has also exhibited cytotoxic activity against breast, renal, melanoma, and central nervous system cancer cell lines [24,29,30]. It was also found to induce apoptosis in the H7PX glioma cell line, through the G2/M cell cycle arrest and DSBs (double-strand

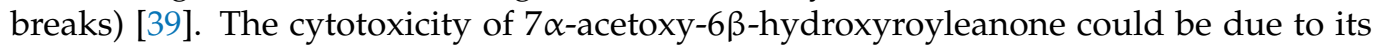
royleanone-type scaffold and by its high lipophilicity, which facilitates penetration into the interior of the cell membrane $[21,22,29,39]$. Moreover, $7 \alpha$-acetoxy- $6 \beta$-hydroxyroyleanone was found to exhibit better activity against Gram-positive bacteria, and more importantly, against MRSA strains than some of the existing antibiotics [37]. Roy is found in many other Plectranthus species like P. madagascariensis, P. grandidentatus, P. actites, P. amboinicus, $P$. sanguineus, P. argentatus, and thus can be considered as a chemomarker of the Plectranthus genus [21,22].

\section{Materials and Methods}

\subsection{Plant Material}

All Plectranthus spp. studied in this work (Table 1) were grown in the "Parque Botânico da Tapada da Ajuda", Lisbon-Portugal from cuttings provided by the Kirstenbosch National Botanical Gardens, South Africa. Plants were collected between 2007 and 2008, always in June and September. Voucher specimens were deposited in the Herbarium "João de Carvalho e Vasconcellos" of the Instituto Superior de Agronomia, Lisboa (LISI), Portugal. The plant names were verified with the Plant List [40]. 


\section{Extraction Procedure}

Plant extracts were obtained by the ultra-sonication method, adding $30 \mathrm{~mL}$ of acetone to $3 \mathrm{~g}$ of ground dry plants ( $P$. hadiensis leaves and the whole plant for the remaining Plectranthus spp.), sonicated for $1 \mathrm{~h}$, and filtered (Whatman No 5 paper, Inc., Clifton, NJ, USA). The extraction procedure was repeated three times until complete extraction [41]. The liquid samples were evaporated at $40-50{ }^{\circ} \mathrm{C}$ using a rotary evaporator (Sigma-Aldrich, IKA HBR 4 basic heating bath, Essen, Germany). All extracts were solubilized in DMSO (10 mg/mL, except for the exceptions that are mentioned) and stored at $-20{ }^{\circ} \mathrm{C}$ until further analysis.

\subsection{Phytochemical Study of P. Hadiensis}

\subsubsection{HPLC-DAD Fingerprint Analysis}

Extract profiling was performed with an Agilent Technologies 1260 Infinity II Series system with diode array detector (DAD; Agilent, Santa Clara, CA, USA), equipped with an Eclipse XDB-C18, $(250 \times 4.0 \mathrm{~mm}$ i.d., $5 \mu \mathrm{m})$ column, from Merck and ChemStation Software (Hewlett-Packard, Alto Palo, CA, USA). Four detection wavelengths were selected: 254, 270, 280, and $360 \mathrm{~nm}$. The mobile phase consisted of a mixture of methanol (A), acetonitrile (B), and $0.3 \%(w / v)$ trifluoroacetic acid in ultrapure water $(\mathrm{C})$. The employed method was modified from the one previously published Matías et al. [21] as follows: $0 \mathrm{~min}, 15 \%$ A, 5\% B, and 80\% C; $10 \mathrm{~min}, 70 \% \mathrm{~A}, 30 \% \mathrm{~B}$, and $0 \% \mathrm{C} ; 25 \mathrm{~min}, 70 \% \mathrm{~A}, 30 \% \mathrm{~B}$, and $0 \%$ $\mathrm{C}$; and $28 \mathrm{~min}, 15 \% \mathrm{~A}, 5 \% \mathrm{~B}$, and $80 \% \mathrm{C}$. The flow rate was set at $1 \mathrm{~mL} / \mathrm{min}$ at room temperature and the injection volume was $20 \mu \mathrm{L}$. Solvents were previously filtered and degassed through a $0.22 \mu \mathrm{m}$ membrane filter. The major peak from the P. hadiensis leaves extract was identified by co-elution, comparing the retention time and UV-vis spectrum overlayed with an authentic standard (Supplementary Materials Figures S2 and S3).

\subsubsection{Isolation and Structural Characterization of $7 \alpha$-Acetoxy- $6 \beta$-Hydroxyroyleanone}

The $P$. hadiensis extract was fractionated by normal phase column chromatography over silica gel using mixtures of n-hexane: EtOAc (8: 2) as eluents to give 3 fractions (A, B, and $C$ ) in order of increasing polarity. Fraction B was further studied using preparative thin-layer chromatography (n-hexane/AcOEt 7:3) on pre-coated TLC sheets (Merck 7747, Darmstadt, Germany) giving 4 fractions B1 to B4. Visualization of spots was performed under visible light and UV light $(\lambda 254$ and $366 \mathrm{~nm})$ followed by spraying with a mixture of $\mathrm{H}_{2} \mathrm{SO}_{4}$ : AcOH: $\mathrm{H}_{2} \mathrm{O}$ (4:80:16) and heating. Fraction $\mathrm{B} 2$ was further purified by preparative chromatography affording its major compound, $7 \alpha$-acetoxy- $6 \beta$-hydroxyroyleanone. The NMR spectra were collected on a Bruker Fourier 300 spectrometer $\left({ }^{1} \mathrm{H} 300 \mathrm{MHz},{ }^{13} \mathrm{C}\right.$ $75 \mathrm{MHz}$ ) using $\mathrm{CDCl}_{3}$ as the solvent. ${ }^{1} \mathrm{H}$ and ${ }^{13} \mathrm{C}$ chemical shifts are expressed in $\delta(\mathrm{ppm})$ and the proton coupling constants $(\mathrm{J})$ in hertz $(\mathrm{Hz})$ Supplementary Materials Table S1.

\subsection{DPPH Radical Scavenging Assay}

The free radical scavenging activity was measured by the DPPH method, as described by Rijo et al. [26]. Briefly, $10 \mu \mathrm{L}$ of each extracted sample (1 mg of dry plant extract $/ \mathrm{mL})$ were added to a $990 \mu \mathrm{L}$ solution of DPPH $(0.002 \%$ in methanol). The mixture was incubated for 30 minutes in the dark, at room temperature. The absorbance (Abs) was measured at $517 \mathrm{~nm}$ (U-1500 Hitachi Instruments, Inc; USA). The positive control used was quercetin $\left(10 \mathrm{mg} / \mathrm{mL}\right.$ in methanol). An absorbance control $\left(\mathrm{Abs}_{\text {control }}\right)$ containing $10 \mu \mathrm{L}$ of methanol and $990 \mu \mathrm{L}$ of DPPH was also prepared. Assays were carried out in triplicate and the free radical scavenging activity was calculated using Equation (1):

$$
\text { Scavenging activity }(\%)=\frac{\mathrm{Abs}_{\text {control }}-\mathrm{Abs}_{\text {sample }}}{\mathrm{Abs}_{\text {control }}} \times 100
$$




\subsection{Antimicrobial Screening Assays \\ 3.4.1. Microorganism Used}

The microorganisms used in this study were obtained from the American Type Culture Collection (ATCC). They included five strains Enterococcus faecalis ATCC 29212, Escherichia coli ATCC 25922, Pseudomonas aeruginosa ATCC 27853, Staphylococcus aureus ATCC 25923, Saccharomyces cerevisiae ATCC 2601, Staphylococcus aureus. CIP were obtained from the CIP 106760, and the yeast strain Candida albicans ATCC 10231.

\subsubsection{Well Diffusion Method}

The antimicrobial activity of each obtained extract was evaluated against two Grampositive bacteria (E. faecalis and S. aureus), two Gram-negative bacteria (E. coli and P. aeruginosa), and two yeasts (S. cerevisiae and C. albicans), according to Rijo et al. [41]. The extracts were diluted in DMSO from $10 \mathrm{mg} / \mathrm{mL}$ to a final concentration of $1 \mathrm{mg} / \mathrm{mL}$. Stock solutions of reference antibiotics (vancomycin, norfloxacin, and nystatin) were also prepared at $1 \mathrm{mg} / \mathrm{mL}$ in DMSO.

In aseptic conditions, Petri dishes containing $20 \mathrm{~mL}$ of solid Mueller-Hinton for bacteria, or Sabouraud Dextrose Agar culture medium (from Biokar Diagnostics), for yeasts, were inoculated with $0.1 \mathrm{~mL}$ of bacterial suspension matching a $0.5 \mathrm{McF}$ arland standard solution and uniformly spread on the medium surface using a sterile swab. Wells of approximately $5 \mathrm{~mm}$ in diameter were made in the medium, using a sterile glass Pasteur pipette, and $50 \mu \mathrm{L}$ of each extract were added into the wells. A positive control of vancomycin for Gram-positive bacteria, norfloxacin for Gram-negative bacteria, and nystatin for yeasts, and a negative control of DMSO, were used in the assay. Plates were incubated at $37^{\circ} \mathrm{C}$ for $24 \mathrm{~h}$. The antimicrobial activity was evaluated by measuring the diameter $(\mathrm{mm})$ of the inhibition zone formed around the wells and compared to controls.

3.4.3. Minimum Inhibitory Concentration (MIC) and Minimum Bactericidal Concentration (MBC)/ Minimum Fungicidal Concentration (MFC)

The MIC and MBC/MFC were determined using the microdilution technique proposed by National Committee for Clinical Laboratory Standards (NCCLS) [42]. Briefly, $100 \mathrm{~mL}$ of Mueller-Hilton broth for bacteria and Sabouraud for yeasts was placed into each well of a 96 microplate, under aseptic conditions. Each extracted sample $(100 \mu \mathrm{L})$, the appropriate positive control of each microorganism, and negative controls at a concentration of $1 \mathrm{mg} / \mathrm{mL}$, were added to the first well. Using a multichannel micropipette, a 1:2 microdilution series was made. A standardized bacterial suspension $(10 \mu \mathrm{L})$, corresponding to $0.5 \mathrm{McFarland}$ of each microorganism, was then placed in all wells. Finally, the plates were incubated at $37^{\circ} \mathrm{C}$ for $24 \mathrm{~h}$. The MIC was determined when no growth was detected in the well of the microplate. Each measurement was performed in triplicate using 96 well microtiter plates with enrichment. A total of $10 \mu \mathrm{L}$ was withdrawn from the microplate and sown in a Petri dish to verify the MBC/MFC, which was determined when there was no visible microbial growth on the plates [43].

\subsection{Evaluation of General Toxicity on Artemia salina Model}

To evaluate the general toxicity of the different extracts and ent-abietane diterpene $7 \alpha$-acetoxy- $6 \beta$-hydroxyroyleanone, a test of lethality to Artemia salina (brine shrimp) was performed as described by Ntungwe et al. [31]. A. salina eggs, dry cyst (JBL GmbH and Co. KG, D-67141 Neuhofen Germany), were hatched in artificial seawater at $25-30{ }^{\circ} \mathrm{C}$ under aeration with a concentration of $35 \mathrm{~g} / \mathrm{L}$. A handmade container with two connected chambers was used for brine shrimp hatching. The eggs were placed in one of two compartments of a container separated by a boundary plate. The cysts were then incubated (in thermostat cabinet AQUA LYTIC ${ }^{\circledR}$, Camberley, Surrey, United Kingdom) for $48 \mathrm{~h}$ at $24{ }^{\circ} \mathrm{C}$. The compartment with the eggs was covered to maintain a dark ambiance. The other compartment was illuminated to attract the phototropic newly hatched nauplii through perforations on the boundary plate. The brine shrimps that had moved to the illuminated 
compartment were collected and used in the lethality assay. Ten to fifteen nauplii were transferred into 24-well plates containing artificial seawater, and $100 \mu \mathrm{L}$ of each sample was added to the wells (final volume per well: $1 \mathrm{~mL}$ ). After $24 \mathrm{~h}$ exposure to the samples $\left(24{ }^{\circ} \mathrm{C}\right)$, the number of dead nauplii (mortality rate $(\%)$ ) was determined (Equation (2)). In addition, $\mathrm{LC}_{50}$ (Lethal Concentration, $50 \%$ ) values $(\mu \mathrm{g} / \mathrm{mL})$ were calculated for the most toxic extracts. DMSO was used as the solvent and was kept at $10 \%(v / v)$ in all samples tested. Potassium dichromate was used as the positive control. All samples were tested in triplicates-at a concentration of 10 ppm for each sample.

$$
\text { () Lethal concentration }(\%)=\frac{\text { Total A. salina }- \text { Alive A. salina }}{\text { Total A. salina }} \times 100
$$

\subsection{Cytotoxicity Screening Assays \\ 3.6.1. Cells and Cell Culture}

Human colon (HCT116), breast adenocarcinoma (MCF-7), lung carcinoma (H460), and triple-negative breast cancer, MDA-MB-231S, cell lines were purchased from ATCC (Rockville, MD, USA). Cell lines were routinely cultured in 293 RPMI-1640 with ultraglutamine or DMEM (MDA-MB-231 cells) medium from Lonza (VWR, 294 Carnaxide, Portugal) supplemented with $10 \%$ fetal bovine serum from Gibco (Alfagene, Carcavelos, Portugal) and maintained in a humidified atmosphere at $37^{\circ} \mathrm{C}$ with $5 \% \mathrm{CO}_{2}$.

\subsubsection{Sulphorhodamine Assay}

The cytotoxicity of five of the most toxic extracts on the brine shrimp lethality bioassay was carried out using the sulforhodamine B (SRB) assay as previously described $[17,44,45]$. Briefly, the extracts were tested in different cancer cell lines: colon colorectal carcinoma (HCT116), human breast adenocarcinoma (MCF-7), and lung cancer carcinoma (H460). Cells were plated in 96-well plates at a final density of $5.0 \times 10^{3}$ cells/well and incubated for $24 \mathrm{~h}$. Cells were then exposed to serial dilutions of each extract (from 1.56 to $50 \mu \mathrm{g} / \mathrm{mL}$ ). The effect of the extracts was analyzed following $48 \mathrm{~h}$ incubation, using the sulforhodamine B (SRB) assay. Briefly, following fixation with $10 \%$ trichloroacetic acid from Scharlau (SigmaAldrich, Sintra, Portugal), plates were stained with $0.4 \%$ SRB from Sigma-Aldrich (Sintra, Portugal) and washed with $1 \%$ acetic acid. The bound dye was then solubilized with $10 \mathrm{mM}$ Tris Base and the absorbance was measured at $510 \mathrm{~nm}$ in a microplate reader (Biotek Instruments Inc., Synergy, MX, USA). The solvent of the extracts (DMSO) corresponding to the maximum concentration used in these assays $(0.25 \%)$ was included as a control. The concentration of extract that causes a $50 \%$ reduction in the net protein increase in cells $\left(\mathrm{IC}_{50}\right)$ was determined for all tested extracts. Data are mean $\pm \mathrm{SEM}$ of 4-5 independent experiments.

\subsubsection{MTT Assay}

MDA-MB231S cell line was grown in DMEM L050-500 culture medium Biowest supplemented with $10 \%$ fetal bovine serum, L-glutamine, and penicillin-streptomycin at $37^{\circ} \mathrm{C}$ and $5 \% \mathrm{CO}_{2}$. For the MTT assay, 1000 cells/well were placed in a 96-well plate and the compound to be tested was added $24 \mathrm{~h}$ after sowing.

The extract and compound were prepared as stock solutions in DMSO (Scrharlau; SU01531000) at a concentration of $20 \mathrm{mg} / \mathrm{mL}$ in the case of the extract (which allowed us to use a reduced DMSO percentage at higher concentrations) and $10 \mathrm{mM}$ in the case of the compound. They were stored at $4{ }^{\circ} \mathrm{C}$. The extract and compound were prepared at different concentrations. For the extract, the following dilutions were made: $80 \mu \mathrm{g} / \mathrm{mL}$, $40 \mu \mathrm{g} / \mathrm{mL}, 20 \mu \mathrm{g} / \mathrm{mL}, 10 \mu \mathrm{g} / \mathrm{mL}$, and $2 \mu \mathrm{g} / \mathrm{mL}$ in culture medium. For the compound, the following dilutions were prepared: $10 \mu \mathrm{M}, 3 \mu \mathrm{M}, 1 \mu \mathrm{M}, 0.3 \mu \mathrm{M}$, and $0.1 \mu \mathrm{M}$. Each concentration was assayed in triplicate in a 96-well plate.

After $48 \mathrm{~h}$ of treatment with the compound or extract, the cells were incubated for $2 \mathrm{~h}$ with MTT. After this time, the culture medium was removed, and the formazan crystals 
were dissolved by adding $200 \mu \mathrm{L}$ of DMSO. The absorbance of each well was measured at $595 \mathrm{~nm}$.

\subsection{Statistical Analysis}

The results were expressed as the mean value \pm SD. Comparisons were performed within groups by the analysis of variance, using the ANOVA with Dunnett's post-test. Significant differences between control and experimental groups were assessed using GraphPad Prism version 5.00 for Windows, GraphPad Software, San Diego, CA, USA, www.graphpad.com, accessed on 5 February 2021. A probability level $p<0.05$ was considered to indicate statistical significance.

\section{Conclusions}

Natural products are known to be an important source of new anticancer agents. This study investigated the diverse biological activity of sixteen Plectranthus extracts. Among the studied extracts, $P$. hadiensis leaves and $P$. mutabilis had the highest percentage extraction yield, antimicrobial and antioxidant activities. P. hadiensis and P. ciliatus were the most cytotoxic extract against HCT116, MCF-7, and H460 cancer cell lines. $7 \alpha$-acetoxy-6 $\beta$ hydroxyroyleanone was isolated from the most cytotoxic extract ( $P$. hadiensis) and was found to be 12 times more bioactive than the extract in the MDA-MB-231S cell line (triplenegative breast cancer). Therefore, it is noteworthy that $7 \alpha$-acetoxy- $6 \beta$-hydroxyroyleanone present in the most cytotoxic extract has interesting antitumoral activities in different cancer cell lines and might thus be responsible for the biological activity of this extract. However further phytochemical studies should be done to find out more compounds that could contribute to the cytotoxicity of $P$. hadiensis.

Supplementary Materials: The following are available online at https:/ / www.mdpi.com/article/10 $.3390 /$ ph14050402/s1, Figure S1: 1H-NMR data information for $7 \alpha$-acetoxy- $6 \beta$-hydroxyroyleanone, Figure S2: HPLC chromatograms $(270 \mathrm{~nm})$ of $P$. hadiensis leaves showing the major compound, $7 \alpha$-acetoxy- $6 \beta$-hydroxyroyleanone, Figure S3: UV spectrum of $7 \alpha$-acetoxy- $6 \beta$-hydroxyroyleanone, Figure S4: Concentration-response curves $\left(\mathrm{IC}_{50} \mu \mathrm{M}\right)$ for $7 \alpha$-acetoxy- $6 \beta$-hydroxyroyleanone; Table S1: NMR spectroscopy data characterization, ${ }^{1} \mathrm{H} \mathrm{NMR}\left(300 \mathrm{MHz}, \mathrm{CDCl}_{3}\right),{ }^{13} \mathrm{C}\left(75 \mathrm{MHz}, \mathrm{CDCl}_{3}\right.$.

Author Contributions: Conceptualization, P.R.; methodology, E.N., L.S., C.T., S.T.-T. and N.A.C.; validation, L.S., A.M.D.-L. and P.R.; investigation, E.N., L.S., C.T., S.T.-T. and N.A.C.; writingoriginal draft preparation, E.N.; writing-review and editing, E.M.D.-M., L.S, A.M.D.-L., P.R. and N.D.; supervision, N.D. and P.R. All authors have read and agreed to the published version of the manuscript.

Funding: This research was funded by Fundação para a Ciência e Tecnologia (FCT) projects UIDB/04567/2020, UIDP/04567/2020, CBIOS/COFAC/FIPID/1/2019 and COFAC/ILIND/CBIOS/ $1 / 2020$. The authors gratefully acknowledge Fundação para a Ciência e Tecnologia (FCT) for the financial support under the reference CBIOS/COFAC/FIPID/1/2019, UIDB/50006/2020, UID/MULTI/ 04378/2013 and the project (3599-PPCDT) PTDC/DTP-FTO/1981/2014-POCI-01-0145-FEDER-016581 and the predoctoral FPU 2019 fellowship from the University of Alcalá awarded to E.M.D-M.

Data Availability Statement: Not applicable.

Acknowledgments: This work was supported by PADDIC 2019 (ALIES-COFAC) as part of the PhD Program in Health Sciences from Universidad de Alcalá and Universidade Lusófona de Humanidades e Tecnologias.

Conflicts of Interest: The authors declare no conflict of interest. The funders had no role in the design of the study; in the collection, analyses, or interpretation of data; in the writing of the manuscript, or in the decision to publish the results. 


\section{References}

1. Wu, C.; Lee, S.L.; Taylor, C.; Li, J.; Chan, Y.M.; Agarwal, R.; Temple, R.; Throckmorton, D.; Tyner, K. Scientific and Regulatory Approach to Botanical Drug Development: A U.S. FDA Perspective. J. Nat. Prod. 2020, 83, 552-562. [CrossRef] [PubMed]

2. Newman, D.J.; Cragg, G.M. Natural Products as Sources of New Drugs over the Nearly Four Decades from 01/1981 to 09/2019. J. Nat. Prod. 2020, 83, 770-803. [CrossRef]

3. World Health Organization (WHO). Fact Sheet on Cancer. Available online: https://www.who.int/news-room/fact-sheets/ detail/cancer (accessed on 5 February 2021).

4. Zhang, X.; Zhang, S.; Yang, Y.; Wang, D.; Gao, H. Natural barrigenol-like triterpenoids: A comprehensive review of their contributions to medicinal chemistry. Phytochemistry 2019, 161, 41-74. [CrossRef] [PubMed]

5. Alam, A.; Jaiswal, V.; Akhtar, S.; Jayashree, B.S.; Dhar, K.L. Isolation of isoflavones from Iris kashmiriana Baker as potential anti proliferative agents targeting NF-kappaB. Phytochemistry 2017, 136, 70-80. [CrossRef] [PubMed]

6. Saksham Garg, A.R. A Current Perspective of Plants as an Antibacterial Agent: A Review. Curr. Pharm. Biotechnol. 2020, 21, 1588. [CrossRef] [PubMed]

7. Arumugam, G.; Swamy, M.K.; Sinniah, U.R. Plectranthus amboinicus (Lour.) Spreng: Botanical, Phytochemical, Pharmacological and Nutritional Significance. Molecules 2016, 21, 369. [CrossRef] [PubMed]

8. Al Musayeib, N.M.; Amina, M.; Al-Hamoud, G.A.; Mohamed, G.A.; Ibrahim, S.R.M.; Shabana, S. Plectrabarbene, a new abietane diterpene from plectranthus barbatus aerial parts. Molecules 2020, 25, 2365. [CrossRef] [PubMed]

9. Garcia, C.; Silva, C.O.; Monteiro, C.M.; Nicolai, M.; Gonz, I.; Ana, M.D. Anticancer properties of the abietane diterpene 6,7-dehydroroyleanone obtained by optimized extraction. Future Med. Chem. 2018, 10. [CrossRef] [PubMed]

10. Pereira, M.; Matias, D.; Pereira, F.; Reis, C.; Simões, M.F.; Rijo, P. Antimicrobial screening of Plectranthus madagascariensis and P. neochilus extracts. Biomed. Biopharm. Res. 2015, 12, 127-138. [CrossRef]

11. Garcia, C.; Teodósio, C.; Oliveira, C.; Oliveira, C.; Díaz-Lanza, A.; Reis, C.; Duarte, N.; Rijo, P. Naturally Occurring Plectranthusderived Diterpenes with Antitumoral Activities. Curr. Pharm. Des. 2019, 24, 4207-4236. [CrossRef]

12. Abdissa, N.; Frese, M.; Sewald, N. Antimicrobial abietane-type diterpenoids from plectranthus punctatus. Molecules 2017, $22,1919$. [CrossRef]

13. Pirttimaa, M.; Nasereddin, A.; Kopelyanskiy, D.; Kaiser, M.; Yli-Kauhaluoma, J.; Oksman-Caldentey, K.M.; Brun, R.; Jaffe, C.L.; Moreira, V.M.; Alakurtti, S. Abietane-Type Diterpenoid Amides with Highly Potent and Selective Activity against Leishmania donovani and Trypanosoma cruzi. J. Nat. Prod. 2016, 79, 362-368. [CrossRef]

14. Isca, V.M.S.; Andrade, J.; Fernandes, A.S.; Paix, P.; Uriel, C.; Mar, A. In Vitro Antimicrobial Activity of Isopimarane-Type Diterpenoids. Molecules 2020, 25, 4250. [CrossRef]

15. Mesquita, L.S.F.; Matos, T.S.; Do Nascimento Ávila, F.; Da Silva Batista, A.; Moura, A.F.; De Moraes, M.O.; Da Silva, M.C.M.; Ferreira, T.L.A.; Nascimento, N.R.F.; Monteiro, N.K.V.; et al. Diterpenoids from Leaves of cultivated Plectranthus ornatus. Planta Med. 2020. [CrossRef]

16. Śliwiński, T.; Sitarek, P.; Skała, E.; Isca, V.M.S.; Synowiec, E.; Kowalczyk, T.; Bijak, M.; Rijo, P. Diterpenoids from Plectranthus spp. As potential chemotherapeutic agents via apoptosis. Pharmaceuticals 2020, 13, 123. [CrossRef]

17. Garcia, C.; Ntungwe, E.; Rebelo, A.; Bessa, C.; Stankovic, T.; Dinic, J.; Díaz-Lanza, A.; Reis, C.P.; Roberto, A.; Pereira, P.; et al. Parvifloron D from Plectranthus strigosus: Cytotoxicity screening of Plectranthus spp. extracts. Biomolecules 2019, 9, 616. [CrossRef]

18. Cretton, S.; Saraux, N.; Monteillier, A.; Righi, D.; Marcourt, L.; Genta-Jouve, G.; Wolfender, J.L.; Cuendet, M.; Christen, P. Anti-inflammatory and antiproliferative diterpenoids from Plectranthus scutellarioides. Phytochemistry 2018, 154, 39-46. [CrossRef]

19. Simões, M.F.; Rijo, P.; Duarte, A.; Barbosa, D.; Matias, D.; Delgado, J.; Cirilo, N.; Rodríguez, B. Two new diterpenoids from Plectranthus species. Phytochem. Lett. 2010, 3, 221-225. [CrossRef]

20. Mothana, R.A.; Al-Said, M.S.; Al-Musayeib, N.M.; El Gamal, A.A.; Al-Massarani, S.M.; Al-Rehaily, A.J.; Abdulkader, M.; Maes, L. In vitro antiprotozoal activity of abietane diterpenoids isolated from Plectranthus barbatus andr. Int. J. Mol. Sci. 2014, 15, 8360-8371. [CrossRef]

21. Matias, D.; Nicolai, M.; Saraiva, L.; Pinheiro, R.; Faustino, C.; Diaz Lanza, A.; Pinto Reis, C.; Stankovic, T.; Dinic, J.; Pesic, M.; et al. Cytotoxic Activity of Royleanone Diterpenes from Plectranthus madagascariensis Benth. ACS Omega 2019, 4, 8094-8103. [CrossRef]

22. Garcia, C.; Isca, V.M.S.; Pereira, F.; Monteiro, C.M.; Ntungwe, E.; Sousa, F.; Dinic, J.; Holmstedt, S.; Roberto, A.; Díaz-Lanza, A.; et al. Royleanone Derivatives from Plectranthus spp. as a Novel Class of P-Glycoprotein Inhibitors. Front. Pharmacol. 2020, 11, 1711. [CrossRef]

23. Isca, V.M.S.; Ferreira, R.J.; Garcia, C.; Monteiro, C.M.; Dinic, J.; Holmstedt, S.; André, V.; Pesic, M.; Dos Santos, D.J.V.A.; Candeias, N.R.; et al. Molecular Docking Studies of Royleanone Diterpenoids from Plectranthus spp. as P-Glycoprotein Inhibitors. ACS Med. Chem. Lett. 2020, 11, 839-845. [CrossRef]

24. Isca, V.M.S.; Sencanski, M.; Filipovic, N.; Dos Santos, D.J.V.A.; Gašparović, A.Č.; Saraíva, L.; Afonso, C.A.M.; Rijo, P.; García-Sosa, A.T. Activity to breast cancer cell lines of different malignancy and predicted interaction with protein kinase $C$ isoforms of royleanones. Int. J. Mol. Sci. 2020, 21, 3671. [CrossRef]

25. Saraiva, N.; Costa, J.G.; Reis, C.; Almeida, N.; Rijo, P.; Fernandes, A.S. Anti-migratory and pro-apoptotic properties of parvifloron $\mathrm{d}$ on triple-negative breast cancer cells. Biomolecules 2020, 10, 158. [CrossRef]

26. Padmapriya, R.; Ashwini, S.; Raveendran, R. In vitro antioxidant and cytotoxic potential of different parts of Tephrosia purpurea. Res. Pharm. Sci. 2017, 12, 31-37. [CrossRef] 
27. Rijo, P.; Batista, M.; Matos, M.; Rocha, H.; Jesus, S.; Simões, M.F. Screening of antioxidant and antimicrobial activities on Plectranthus spp. extracts. Biomed. Biopharm. Res. 2012, 9, 225-235. [CrossRef]

28. Andrade, J.M.; Domínguez-Martín, E.M.; Nicolai, M.; Faustino, C.; Rodrigues, L.M.; Rijo, P. Screening the dermatological potential of plectranthus species components: Antioxidant and inhibitory capacities over elastase, collagenase and tyrosinase. J. Enzym. Inhib. Med. Chem. 2021, 36, 257-269. [CrossRef]

29. Ndjoubi, K.O.; Sharma, R.; Badmus, J.A.; Jacobs, A.; Jordaan, A.; Marnewick, J.; Warner, D.F.; Hussein, A.A. Antimycobacterial, Cytotoxic, and Antioxidant Activities of Abietane Diterpenoids Isolated from Plectranthus madagascariensis. Plants 2021, 10, 175. [CrossRef]

30. Matias, D.; Nicolai, M.; Fernandes, A.S.; Saraiva, N.; Almeida, J.; Saraiva, L.; Faustino, C.; Díaz-Lanza, A.M.; Reis, C.P.; Rijo, P. Comparison study of different extracts of Plectranthus madagascariensis, P. neochilus and the rare P. porcatus (lamiaceae): Chemical characterization, antioxidant, antimicrobial and cytotoxic activities. Biomolecules 2019, 9, 179. [CrossRef]

31. Ntungwe, N.E.; Marçalo, J.; Garcia, C.; Reis, C.; Teodósio, C.; Oliveira, C.; Oliveira, C.; Roberto, A. Biological activity screening of seven Plectranthus species. J. Biomed. Biopharm. Res. 2017, 14, 95-108. [CrossRef]

32. Mogana, R.; Adhikari, A.; Tzar, M.N.; Ramliza, R.; Wiart, C. Antibacterial activities of the extracts, fractions and isolated compounds from Canarium patentinervium miq. Against bacterial clinical isolates. BMC Complement. Med. Ther. 2020, 20, 55. [CrossRef] [PubMed]

33. Ntungwe, N.E.; Domínguez-Martín, E.M.; Roberto, A.; Tavares, J.; Isca, V.M.S.; Pereira, P.; Cebola, M.-J.; Rijo, P. Artemia species: An Important Tool to Screen General Toxicity Samples. Curr. Pharm. Des. 2020, 26, 2892-2908. [CrossRef] [PubMed]

34. Srisawat, T.; Chumkaew, P.; Heed-Chim, W.; Sukpondma, Y.; Kanokwiroon, K. Phytochemical screening and cytotoxicity of crude extracts of vatica diospyroides Symington type LS. Trop. J. Pharm. Res. 2013, 12, 71-76. [CrossRef]

35. Kathryn, J.; Sireesha, V.; Stanley, L. Triple Negative Breast Cancer Cell Lines: One Tool in the Search for Better Treatment of Triple Negative Breast Cancer. Breast Dis. 2012, 32, 35-48. [CrossRef]

36. Burmistrova, O.; Simões, M.F.; Rijo, P.; Quintana, J.; Bermejo, J.; Estévez, F. Antiproliferative activity of abietane diterpenoids against human tumor cells. J. Nat. Prod. 2013, 76, 1413-1423. [CrossRef]

37. Bernardes, C.E.S.; Garcia, C.; Pereira, F.; Mota, J.; Pereira, P.; Cebola, M.J.; Reis, C.P.; Correia, I.; Piedade, M.F.M.; Minas Da Piedade, M.E.; et al. Extraction Optimization and Structural and Thermal Characterization of the Antimicrobial Abietane $7 \alpha$-Acetoxy-6 $\beta$-hydroxyroyleanone. Mol. Pharm. 2018, 15, 1412-1419. [CrossRef]

38. Abdel-Mogib, M.; Albar, H.A.; Batterjee, S.M. Chemistry of the genus Plectranthus. Molecules 2002, 7, 271-301. [CrossRef]

39. Sitarek, P.; Toma, M.; Ntungwe, E.; Kowalczyk, T.; Skała, E.; Wieczfinska, J.; Śliwiński, T.; Rijo, P. Insight the biological activities of selected abietane diterpenes isolated from Plectranthus spp. Biomolecules 2020, 10, 194. [CrossRef]

40. The Plant List. Version 1.1. 2013. Available online: http://www.theplantlist.org/ (accessed on 1 January 2021).

41. Rijo, P.; Matias, D.; Fernandes, A.S.; Simões, M.F.; Nicolai, M.; Reis, C.P. Antimicrobial plant extracts encapsulated into polymeric beads for potential application on the skin. Polymers 2014, 6, 479-490. [CrossRef]

42. CLSI Padronização dos Testes de Sensibilidade a Antimicrobianos por Disco-difusão. In Norma Aprovada—Oitava Edição; NCCLS: Wayne, PA, USA, 2003; Volume 23, ISBN 1-56238-485-6.

43. Brandão, F.; Isabel, M.; Ramos, L.; Miyagusku, L. Antimicrobial activity of hydroalcoholic extracts from genipap, baru and taruma. Cienc. Rural 2017, 47, 6-11. [CrossRef]

44. Leão, M.; Soares, J.; Gomes, S.; Raimundo, L.; Ramos, H.; Bessa, C.; Queiroz, G.; Domingos, S.; Pinto, M.; Inga, A.; et al. Enhanced cytotoxicity of prenylated chalcone against tumour cells via disruption of the p53-MDM2 interaction. Life Sci. 2015, 142, 60-65. [CrossRef]

45. Soares, J.; Pereira, N.A.; Monteiro, Â.; Leão, M.; Bessa, C.; Dos Santos, D.J.; Raimundo, L.; Queiroz, G.; Bisio, A.; Inga, A.; et al. Oxazoloisoindolinones with in vitro antitumor activity selectively activate a p53-pathway through potential inhibition of the p53-MDM2 interaction. Eur. J. Pharm. Sci. 2015, 66, 138-147. [CrossRef] 